http://www.inderscience.com/info/inarticle.php?artid=77195

\title{
Abstract
}

Nations around the world are bent on creating an efficient and inclusive socio-economic environment and ethos for enterprises and business. The aim is to create a business setting and system of innovation in which standard macroeconomic policies are more effective and increase private sector development and economic growth.

The research and innovation system in Central Europe (CE) has not been studied in sufficient depth, at either the theoretical or empirical level. Apart from their similar pattern of transition from planned to mixed economy, the national research and innovation systems of the selected countries evolved into rather diverse systems in terms of their size, enterprise composition, research intensity and structural configuration. The countries' economic profiles play a crucial role in their integration with the EU and their global competiveness. The economic structure, level of research, technological development, human resources in science and technology (HRST), innovation, and SME competitiveness clearly testify to the diverse level of the region's economic competitiveness.

The aim of this article is to describe the differences among selected Central European countries in order to demonstrate that efforts to build a single European innovation system are still far from complete. Selected composite indices such as the Global Innovation Index (GII), the Networked Readiness Index (NRI), and the Global Enabling Trade Index (ETI) show that countries in Central Europe need improvements in terms of competitiveness, innovation and technology development. Economies' performance as regards the environment for entrepreneurs was also analysed based on several composite indices with sufficient complexity to capture the multidimensional nature of entrepreneurship.

The article concludes that an efficient use of European structural and investment funds (ESIF) and the application of smart specialisation strategies are promising mechanisms for European integration processes.

Keywords: CE countries, entrepreneurship environment, composite indices, innovation and research policies, facilitating institutions 


\section{A Multidimensional Approach to the Environment for Entrepreneurship in Selected CE Countries}

“... a social system consists in a plurality of individual actors interacting with each other in a situation which has at least a physical or environmental aspect, actors who are motivated in terms of a tendency to the 'optimization of gratification' and whose relation to their situations, including each other, is defined and mediated in terms of culturally structured and shared symbols."

(Parsons 1964, pp. 5-6)

\section{Introduction}

Over the last couple of decades, the emerging economies of Central Europe (in this paper represented by Poland, the Czech Republic, Hungary, Slovenia and Croatia), which in the 1990s made a transition from a centrally-planned to a market economy, successfully developed national policies and innovation systems in order to foster innovation and draw nearer to developed European countries. Their success need not only be measured in terms of concepts and policies, but also in terms of growth and competitiveness. Once closed behind the Iron Curtain and entirely under Soviet control (except in the case of Croatia and Slovenia), these countries had a poor understanding of innovation as a process of creative destruction that is initiated by an entrepreneur and in which innovation is an essential driver of economic growth and the "capitalist machine." Furthermore, they had no concept of a national innovation system (Freeman) and its purpose. Nevertheless, Hungary, the Czech Republic, Poland, Slovenia and Croatia came under pressure of massive socio-economic transformations and learnt their lesson fast.

These economies "emerged" as they broke free from the confines of post-socialism and transformed themselves into modern capitalist economies. The rise of neoliberalism was symbolically marked by the fall of the Berlin Wall in 1989, an event that ushered in a time of huge change in culture, politics, society, business and technology. The transformation of the emerging European economies spurred the processes of globalisation and the rapd development of information technologies, which swept the globe.

Even though these countries (similar to other new member states) experienced significant economic growth, especially before the global financial crisis, and managed to narrow their gap with leading nations, they remained far behind those European countries that were more developed scientifically and technologically (Archibugi and Filippetti, 2011). The global crisis hit the less developed countries much harder than developed ones and widened the gap between these two groups of countries. The worst affected was Croatia, which did not return to a path of economic growth until the last quarter of 2015.

Central and Eastern European countries have experienced a lot of pressure recently. Tensions between the EU and Russia over the situation in Ukraine and mutual economic sanctions have affected production, consumer confidence, exports, and investment throughout the region. Moreover, as the German economy experienced inconsistent growth from mid-2014 onwards, Central and Eastern European countries suffered further setbacks (EIU 2015).

The data presented in this article show that there is a development gap between "old" and "new" member states, and that the new member states in Central Europe differ significantly in socio-economic development. This points to the need for better coordination of innovation polices at the regional level to establish a well-balanced and uniform EU innovation system 
that would be competitive globally. A multidimensional approach has been applied that looks at all the facets of entrepreneurship from the entrepreneur to the business, the start-up process and the surrounding environment (Lumpkin and Dess, 1996).

\section{Central European emerging economies: an overview}

Creating an efficient and inclusive socio-economic environment and business ethos for enterprises is in the best interest of all countries. It should help in creating a business setting in which standard macroeconomic policies will be more effective and increase private sector development and economic growth. Economies' performance as regards the environment for entrepreneurs in selected CE countries (the Czech Republic, Croatia, Hungary, Poland and Slovenia) was analysed based on several composite indices (Table 1) which successfully capture the multidimensional nature of entrepreneurship.

The transition process started in Poland in the early 1980s and continued with the 1989 Velvet Revolution in Czechoslovakia, which peacefully split into the Czech Republic and Slovakia in 1993. Hungary's transition to a Western-style democracy was also peaceful, while Slovenia gained independence from the former Yugoslavia after a brief conflict. Croatia, meanwhile, had to fight for its independence in a bloody, destructive war. The privatisation of many stateowned production facilities failed to produce the desired results. Production facilities were either destroyed in the process of transition or outmoded products from CE countries could not compete on international markets. On the economic front, the shift to modern capitalist economies included the collapse of "real socialism" and a rise of neoliberalism, which was symbolically marked by the fall of the Berlin Wall in 1989.

On their EU accession path, candidate countries received sizable financial support through PHARE, IPA, SAPARD, CARDS and similar funds aimed at facilitating economic recovery and integration with the European Union. These funds have since been replaced by the European Structural and Investments Funds (ESIF), which strongly influenced innovation policies by supporting programmes for the development of infrastructure, human resources, industry and regional collaboration, research and innovation. Poland, Hungary, the Czech Republic and Slovenia finally joined the EU in 2004. Croatia followed suit in 2013.

In order to reduce the disparities between the "old" and "new" member states, a comprehensive process of EU integration has been put in place on two key levels: (i) a political one, encompassing all the legislation, policies and programmes associated with accession, and (ii) an economic one, driven mainly by foreign direct investment (FDI) and Structural Funds. The integration process reinforces the current debate on the role of innovation in Central Europe. Innovation and the application of new technologies in different entrepreneurial sectors across Central European countries represent a good starting point for a discussion on their economic development. In order to upgrade innovation capacities and ensure a higher added value of products and services, a number of institutional and strategic competitiveness reforms have been undertaken in these countries. Since implementing an innovation policy is a structural process, many questions arise. For instance: What changes are necessary in the SME sector in post-socialist Central European countries, in terms of both institutional structure and processes, in order to create a more creative and competitive economy? 
The national innovation and research policies and the current status of innovation in the Central European countries are largely determined by the common European strategy of research and innovation. Fostering innovation became a strategic goal in the mid-1990s (First Action Plan for Innovation in Europe) as Europe experienced growing unemployment, economic stagnation and fierce competition from the United States, Japan, South Korea and China (European Commission, 2011). Acknowledging the importance of new knowledge for long-term economic growth (Archibugi \& Coco, 2005), the Lisbon strategy (European Council, 2000) and the relaunched Lisbon strategy (European Commission, 2005) both focus on transforming the European Union into a highly competitive and knowledge-based economy. The Europe 2020 strategy (European Commission, 2011) and the European Union Flagship Initiative (European Commission 2010) emphasise Smart (education, research/innovation), Sustainable (digital society, low-carbon economy) and Inclusive (high level of employment) growth. This strategic vision can only be realised through coordinated supranational policy actions aimed at integration and harmonisation in science, education and innovation, including the creation of the European Research Area (ERA), the Horizon 2020 programme (European Commission 2011a), the creation of the European Higher Education Area (EHEA), and the introduction of the European Innovation Trend Chart/Innovation Union Scoreboard (IUS) (European Commission,2002).

Although the first framework programme for research and technology started as a process of cooperation among industrially advanced countries ${ }^{1}$, being included in common EU programmes for fostering innovation and research is now an imperative for all the countries, regardless of their scientific and technological sophistication. This cannot be explained solely by the impact of globalisation on science and technology; the strong interdependence of EU economies plays a significant role as well. Reforms, or a lack of them, in one country affect the performance of other countries. Therefore, policies governing scientific and innovation activities in Europe aim to include all countries in EU programmes. The EU's decisions on research programmes and funding dictate the dynamics and direction of research and the technological trajectories for all the countries in the region. Consequently, the EU's actions strongly influence national research strategies, and exclusion from common research programmes has an adverse effect on national science polices. Moreover, national authorities are strongly pushing for cooperation with Europe as using ESIF funds makes national innovation and research actors more competitive.

Although there are several possible scenarios for the future governance of science, technology and innovation policy in Europe, including one based on progressive decentralisation, it seems that Kuhlmann's (Kuhlmann, 2001) scenario of "co-evolution of 'postnational' political and innovation systems towards centrally mediated policymaking" will be fulfilled.

The countries' economic profiles play a crucial role in their integration with the EU and their global competiveness. The economic structure, the level of research, technological development, innovation and SME competitiveness speak volumes about the economic competitiveness of regions.

\footnotetext{
${ }^{1}$ The first "framework programme" for research and technology, launched in 1984, focused on industrial technologies, information technology, telecommunications and biotechnology (Kuhlmann, 2001).
} 
Figure 1: GDP growth rate, 2004-2013

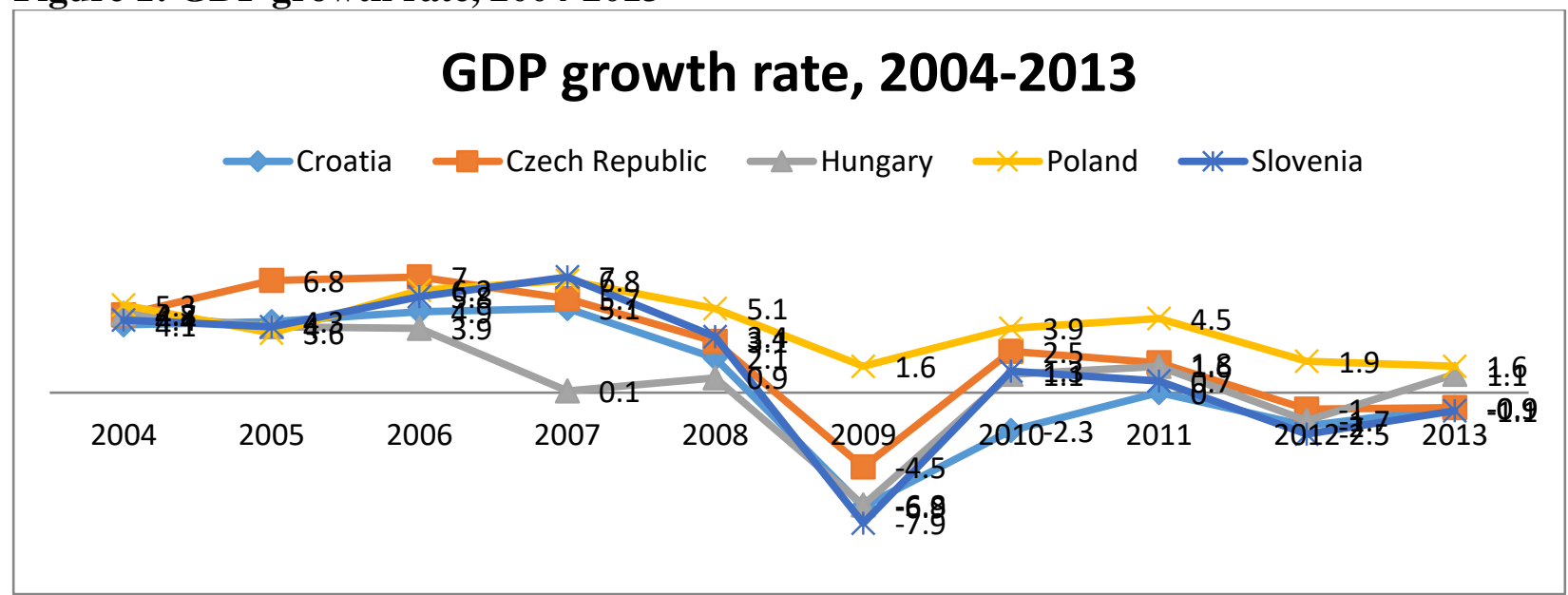

Source: Author's work based on the Eurostat online database (accessed: 2 May 2015).

All the studied countries experienced a major economic downturn in 2009 due to the global financial crisis. Croatia, Slovenia and Hungary were the most severely affected as the decline in their GDP growth rates ranged from $6.8 \%$ in Hungary to $7.9 \%$ in Slovenia and Croatia (Figure 1). The Czech GDP declined by $4.5 \%$, while Poland recorded 1.6\% GDP growth. The increase in Poland's GDP is mainly attributed to the country's strong industrialisation after its accession to the EU and a strong internal market. Despite fluctuations in economic growth after the crisis, Poland and Hungary retained their positive growth, while all the other countries experienced an economic decline. This shows that transition Central European countries still suffer from structural deficits associated with the poor competitiveness of enterprises, inadequate business climate, corruption and bloated administration.

The countries differ significantly in terms of population size and other economic indicators (Table 1).

Table 1: Some comparative indicators for selected CE countries, 2013

\begin{tabular}{r|lllll} 
& $\begin{array}{l}\text { Population } \\
(2013)\end{array}$ & $\begin{array}{l}\text { Area } \\
\left(\mathrm{km}^{2}\right)\end{array}$ & $\begin{array}{l}\text { GDP per } \\
\text { capita }(P P P), \\
\text { euro, 2013 }\end{array}$ & $\begin{array}{l}\text { GDP per } \\
\text { capita }(P P P), \\
\text { 2013 Index } \\
(\text { EU28 }=100)\end{array}$ & $\begin{array}{l}\text { Unemployme } \\
\text { nt rate } \\
(2013)\end{array}$ \\
\hline $\begin{array}{r}\text { Czech } \\
\text { Republic }\end{array}$ & $10,516,125$ & 78.864 & 20,600 & 80 & 7.0 \\
Croatia & $4,262,140$ & 56,538 & 15,600 & 61 & 17.3 \\
Hungary & $9,908,798$ & 93.030 & 17,200 & 67 & 10.2 \\
Poland & $38,533,299$ & 312.685 & 17,500 & 68 & 10.3 \\
Slovenia & $2,058,821$ & 20.254 & 21,300 & 83 & 10.1
\end{tabular}

Source: Author's work based on the Eurostat online database (accessed 3 May 2015) http://ec.europa.eu/eurostat/web/national-accounts/data/main-tables 
Slovenia has the strongest economy with a per capita GDP of $€ 21,300$, i.e. around $81 \%$ of the EU27 average. Its economy was growing since the country became independent, but the latest economic crisis has hampered it seriously and Slovenia's index of economic development has been dropping since 2008. Slovenia has returned to its growth path thanks to drastic economic and financial measures.

Poland is the seventh-largest economy in the EU28, accounting for 2.94\% of the EU28's 2012 GDP. The country maintains one of the highest positive GDP growth rates and is one of the fastest growing EU28 economies (Eurostat, 2013). Together, Poland, the Czech Republic and Hungary (Table 6) account for around $15 \%$ of all companies in the EU.

After a $4.5 \%$ drop in real GDP in 2009, the Czech economy slowly recovered for two successive years, but the positive trend was stopped in 2012.

Hungary's GDP increased by $1.2 \%$ in real terms in 2013 , mainly due to a surge in public investment that also included investment projects co-funded by the European Union. It is expected that this trend will continue throughout the 2014-2020 period.

Following a period of economic growth between 2002 and 2008, Croatia went into a seven-year recession, which constitutes a precedent among EU economies. The period of rapid economic growth from 2002 to 2008 with an average annual GDP growth rate of 5\% was followed by seven years of economic recession, resulting in an economic downturn and a cumulative decrease in GDP of over 12\%. Yet the Croatian economy is the most developed in Southeast Europe, with a 2013 GDP per capita of $€ 15,600$, or around $61 \%$ of the EU27 average.

Creating an efficient and inclusive ethos for enterprises and business is in the interest of all countries. This should help to create an environment in which standard macroeconomic policies will be more effective and infuse the economy more easily. We analysed the rankings of economies' performance in terms of the environment for entrepreneurs in selected CE countries on the basis of several composite indices (Table 2). These complex indices successfully capture the multidimensional nature of entrepreneurship. The most competitive countries in terms of ease of doing business and business environment are Slovenia and Poland, which topped the Global Entrepreneurship and Development Index (GEDI Index), where Slovenia took $24^{\text {th }}$ place and Poland was $27^{\text {th }}$ among 121 countries. As regards the Doing Business Index, Slovenia is ranked $33^{\text {rd }}$ and Poland $45^{\text {th }}$ among 189 countries. They are followed by the Czech Republic and Hungary, while Croatia is facing many difficulties in creating an enabling business environment and appropriate institutions to foster business competitiveness.

The Corruption Perception Index scores for CE countries range from 48 to 60 . A country's score indicates the perceived level of public sector corruption, which poses a serious problem for the business environment. Poland, with a Corruption Perception Index score of 60, was perceived to be the least corrupt country in 2013. Slovenia was the second-least corrupt country, with a score of 57. Hungary was in third place, with 54, and Croatia and the Czech Republic shared the last place, each with an index score of 48. 
Table 2. Business environment by selected composite indices

\begin{tabular}{|c|c|c|c|c|c|}
\hline Country & $\begin{array}{l}\text { Economic } \\
\text { Freedom } \\
\text { Index (EFI), } \\
(2014), \\
\text { ranking } 178 \\
\text { countries }\end{array}$ & $\begin{array}{l}\text { Doing } \\
\text { Business } \\
\text { Index } \\
(2014), \\
\text { ranking } 189 \\
\text { countries }\end{array}$ & $\begin{array}{l}\text { Corruption } \\
\text { Perceptions } \\
\text { Index (CPI) } \\
(2013), \\
\text { ranking } 177 \\
\text { countries }\end{array}$ & $\begin{array}{l}\text { KOF } \\
\text { Globalization } \\
\text { Index (2014) }\end{array}$ & $\begin{array}{l}\text { Global } \\
\text { Entrepreneurship } \\
\text { \& Development } \\
\text { Index (GEDI), } \\
\text { (2014), } \\
\text { ranking } 121 \\
\text { countries }\end{array}$ \\
\hline Poland & 50 (score 67) & 45 & 38 (score 60$)$ & 25 & 27 (score 49.01 ) \\
\hline $\begin{array}{r}\text { Czech } \\
\text { Republic }\end{array}$ & 26 (score 72.2$)$ & 75 & 57 (score 48$)$ & 16 & 42 (score 44.6$)$ \\
\hline Hungary & $\begin{array}{l}51 \text { (score } \\
67.0)\end{array}$ & 54 & 47 (score 54$)$ & 9 & 43 (score 44.5$)$ \\
\hline Slovenia & $\begin{array}{l}74 \text { (score } \\
62.7)\end{array}$ & 33 & 43 (score 57 ) & 29 & 24 (score 52.7 \\
\hline Croatia & $\begin{array}{l}87 \text { (score } \\
60.4)\end{array}$ & 89 & 57 (score 48$)$ & 33 & $50($ score 40.9$)$ \\
\hline
\end{tabular}

Note: score 0-100

Sources: World Bank, Doing Business report 2014/2015; KOF GI: http://www.doingbusiness.org/rankings; http://globalization.kof.ethz.ch/

CPI (http://www.transparency.org/cpi2013/results); EFI ( http://www.heritage.org/index/)

GEDI (http://www.ranking-lists.com/countries/countries/2014-global-entrepreneurship-development-index)

As regards economic freedom, the Czech Republic is the highest-ranked country, with a score of 72.2 in 2014. Hungary and Poland share second place, each with a score of 67 in 2014. Slovenia is in fourth place, with 62.7, while Croatia is last with 60.4. According to the Globalization Index 2014, Hungary is the ninth-most globalised country in the world. Other analysed CE countries dominate the top 33 in terms of the annual Globalization Index (among 192 countries listed in 2014).

Table 3 presents the results of the five selected countries from Central Europe in terms of competitiveness, innovation and technology development as assessed by a set of composite indices. All the selected CE countries except Croatia recorded a drop in the rankings compared with the 2010-2011 ranking. Following the lead of the highest-ranked economies in the EU and globally, the selected CE countries need to transform themselves into knowledge economies. The countries' competitiveness would be enhanced by improvements in their performance-related technological readiness and innovation ecosystems. The trends data in other composite indicesthe Global Innovation Index (GII), the Networked Readiness Index (NRI), and the Global Enabling Trade Index (ETI) — also clearly indicate areas where improvements are most needed. 
Table 3. Competitiveness, innovation and technological development at the global and regional levels, selected Central European countries, 2009-2014

\begin{tabular}{|c|c|c|c|c|c|c|c|c|c|c|}
\hline COUNTRY & $\begin{array}{l}\text { WEF } \\
\text { GCI, } \\
\text { (GCR } \\
2010- \\
2011)\end{array}$ & $\begin{array}{l}\text { WEF - } \\
\text { GCI, } \\
\text { (GCR } \\
\text { 2014- } \\
\text { 2015) }\end{array}$ & $\begin{array}{l}\text { INSEAD-GII } \\
2009-2010\end{array}$ & $\begin{array}{l}\text { INSEAD- } \\
\text { GII2014 }\end{array}$ & $\begin{array}{l}\text { WEF GITR } \\
2009 / 2010_{-} \\
\text {NRI }\end{array}$ & $\begin{array}{l}\text { WEF } \\
\text { GITR NRI } \\
2014\end{array}$ & $\begin{array}{l}\text { WEF } \\
\text { GETRI - } \\
\text { ETI,2010 }\end{array}$ & $\begin{array}{l}\text { WEF } \\
\text { GETRI - } \\
\text { ETI,2012 }\end{array}$ & IUS SII & $\begin{array}{l}\text { IUS } \\
2013 \\
\text { SII }\end{array}$ \\
\hline RANK & $\begin{array}{l}139 \\
\text { COUNTR } \\
\text { IES }\end{array}$ & $\begin{array}{l}144 \\
\text { COUNTR } \\
\text { IES }\end{array}$ & $\begin{array}{l}132 \\
\text { COUNTR } \\
\text { IES }\end{array}$ & $\begin{array}{l}143 \\
\text { COUNTR } \\
\text { IES }\end{array}$ & $\begin{array}{l}133 \\
\text { COUNTR } \\
\text { IES }\end{array}$ & $\begin{array}{l}148 \\
\text { COUNTR } \\
\text { IES }\end{array}$ & $\begin{array}{l}132 \\
\text { COUNTR } \\
\text { IES }\end{array}$ & $\begin{array}{l}132 \\
\text { COUNTR } \\
\text { IES }\end{array}$ & 2010 & 2013 \\
\hline SLOVENIA & 45 & 70 & 26 & 28 & 31 & 36 & 35 & 33 & 0,481 & 0,513 \\
\hline CROATIA & 77 & 77 & 45 & 42 & 51 & 46 & 45 & 46 & 0,315 & 0,306 \\
\hline POLAND & 48 & 43 & 38 & 45 & 48 & 54 & 58 & 48 & 0,272 & 0,279 \\
\hline HUNGARY & 52 & 60 & 36 & 35 & 46 & 47 & 49 & 47 & 0,341 & 0,351 \\
\hline $\begin{array}{l}\text { CZECH } \\
\text { REPUBLIC }\end{array}$ & 36 & 37 & 27 & 26 & 36 & 42 & 42 & 41 & 0,411 & 0,422 \\
\hline
\end{tabular}

Explanation:

drop compared to previous period

growth compared to previous period

Sources:

same position

GCI 2010-2011;

WIPO, Cornell University and INSEAD - the Global Innovation Index (GII) 2014; INSEAD GII 2009-2010

WEF GITR-2014 - NRI2014; NRI 2009-2010;

WEF GETRI ETI2012; ETI 2010

Innovation Union Scoreboard (IUS) 2014, SII 2010, 2013. 
The Central European countries differ significantly in terms of the scale of entrepreneurship in specific sectors, as shown in Table 4. According to the type of activity start-ups focus on, Poland is the most production-oriented economy in Europe, with $41 \%$ of start-ups and early-stage enterprises in production industries. Slovenia follows with $28.3 \%$. Croatia has the smallest proportion of start-up companies in the production sector, at $18 \%$. Overall, the proportion of production industry enterprises declined from $47 \%$ in 2011 to $41 \%$ in 2012 , chiefly in favour of extraction industries and $\mathrm{B} 2 \mathrm{C}$ services $^{2}$.

Table 4. Early-stage entrepreneurship (TEA) by economy sector in the Central European countries and in the United States (\%)

\begin{tabular}{r|llll} 
Country & Extraction & Production & B2B services & B2C services \\
\hline Croatia & 13.1 & 18.0 & 26.7 & 42.2 \\
Czech Republic & $:$ & $:$ & $:$ & $:$ \\
Hungary & 12.2 & 26.2 & 23.4 & 38.2 \\
Poland & 6.7 & 41.3 & 18.1 & 33.9 \\
Slovenia & 3.8 & 28.3 & 41.8 & 26.1 \\
USA & 3.6 & 21.9 & 33.2 & 41.3 \\
\hline
\end{tabular}

\section{Sources:}

GEM, 2013: 24; data not available for the Czech Republic.

As regards the share of start-ups in the B2C service sector (Table 5), Croatia (42.2\%) and Hungary (38.2\%) top the list, while Poland follows (34\%) and Slovenia is in last place (26\%). The true indicator of advanced economic development, however, is the share of start-ups in B2B services. Although Slovenia's TEA index is low in overall terms, at 5.4\%, the country has the highest share of enterprises active in the B2B service sector (42\%). The countries with the lowest proportions of entrepreneurs starting a business in the B2B service sector are Poland $(18.1 \%)$ and Hungary $(23.4 \%)$.

The next figure compares SME impacts in the EU27/EU28 and Central Europe. The number of SMEs, employment in SMEs, and value added at factor costs by SMEs in the studied CE countries are almost equal to the EU27/EU28 average (Figure 2). A slight difference can be seen in the number of those employed in SMEs, where the number is higher in the CE countries. Also, value added at factor costs by SMEs is slightly higher in the EU27 than in the studied CE countries. Therefore SMEs in the EU27/28 as a whole are more productive and employ fewer people than in Central Europe. This may be due to the higher levels of capital in EU27/28 countries as a whole.

\footnotetext{
${ }^{2}$ GEM (2014) identifies four categories of economy sectors: extraction, production, business-to-business (B2B)
} services, and business-to-customer (B2C) services. 
Figure 2. Number of SMEs, employment, and value added in the EU27/28 and in Central European countries, 2008-2015

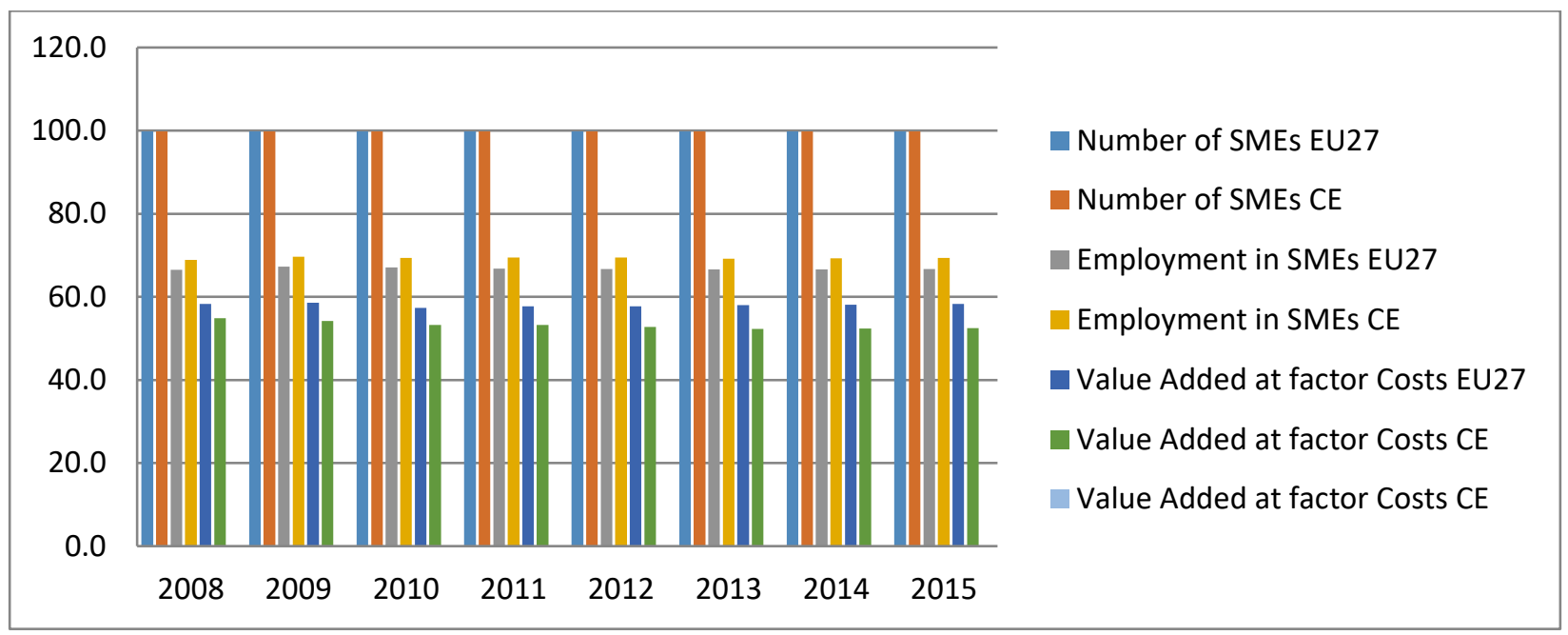

Source: Eurostat SBS database, DIW, DIW econ.

The 2013 data (Table 6) show that the business economy ${ }^{3}$ of the studied Central European countries (CE) consisted of some 3.27 million active enterprises (16\% of the EU27 total) with a combined 15.76 million employees (12\% of the EU27 total). In the EU as a whole and in the five Central European countries, the service sector accounted for approximately three-quarters of the total number of active enterprises. In Hungary, the service sector was even more dominant, with $79 \%$ of all enterprises. The lowest proportion of service enterprises was found in the Czech Republic, at $66 \%$.

\footnotetext{
${ }^{3}$ Statistical data on business demography in the European Union (EU) comprises aspects such as the total number of active enterprises in the business economy, their birth rates, death rates, and the survival rate. In the business demography domain, the business economy covers sections B to N, excluding activities of holding companies - K64.2 (NACE Rev.2).
} 
The 2013 data (Table 5) show that the business economy ${ }^{4}$ of the selected Central European countries (CE) consisted of 3.27 million active enterprises (16\% of the EU27 total) with 15.76 million employees (12\% of the EU27 total).

Table 5. Number of enterprises in the EU and the studied CE countries, 2013

\begin{tabular}{|c|c|c|c|c|c|c|c|c|c|c|}
\hline \multirow[b]{2}{*}{$\begin{array}{l}\text { Size } \\
\text { class }\end{array}$} & \multicolumn{8}{|c|}{$\begin{array}{l}\text { Number of enterprises } \\
\text { NACE Rev. } 2 \text { All sections (B-J, L-N) }\end{array}$} & \multicolumn{2}{|c|}{$\begin{array}{l}\text { Number of persons } \\
\text { employed }\end{array}$} \\
\hline & EU27 & $\begin{array}{l}\text { CE } \\
\text { selected } \\
\text { countries }\end{array}$ & $\begin{array}{l}\text { CE (as } \\
\% \text { of } \\
\text { EU27) }\end{array}$ & $\begin{array}{l}\text { Czech } \\
\text { Republic }\end{array}$ & Croatia & Hungary & Poland & Slovenia & EU27 & $\begin{array}{l}\text { CE } \\
\text { selected } \\
\text { countries }\end{array}$ \\
\hline $0-9$ & $19,340,620$ & $3,117,631$ & $16 \%$ & 968,997 & 134,208 & 497,948 & $1,407,429$ & 109,049 & $37,498,442$ & $5,498,558$ \\
\hline $10-49$ & $1,356,679$ & 123,987 & $9 \%$ & 31,851 & 10,090 & 23,903 & 52,675 & 5,468 & $26,955,135$ & $2,506,519$ \\
\hline $50-249$ & 220,888 & 27,982 & $12 \%$ & 6,271 & 1,716 & 4,067 & 14,850 & 1,078 & $22,632,328$ & $2,900,588$ \\
\hline $250+$ & 43,089 & 5,774 & $13 \%$ & 1,406 & 388 & 825 & 2,940 & 215 & $43,763,452$ & $4,851,488$ \\
\hline Total & $20,961,270$ & $3,275,376$ & $16 \%$ & $1,008,526$ & 146,399 & 526,749 & $1,477,893$ & 115,809 & $130,849,357$ & $15,757,154$ \\
\hline $\begin{array}{l}\text { All } \\
\text { SMEs }\end{array}$ & $20,918,187$ & $3,269,600$ & $15 \%$ & $1,007,119$ & 146,014 & 525,918 & $1,474,954$ & 115,595 & $87,085,906$ & $10,905,665$ \\
\hline
\end{tabular}

Source: Eurostat SBS database, provided by DIW, DIW econ, SME Performance Review 2013/2014.

Note: 2013 data estimation DIW; all SMEs (include enterprises size class: 0-9;10-49;50-249).

\footnotetext{
${ }^{4}$ Statistical data on business demography in the European Union (EU) covers aspects such as the total number of active enterprises in the business economy, their birth rates, death rates, and the survival rate. In the business demography domain, the business economy covers sections B to N, excluding the activities of holding companies - K64.2 (NACE Rev.2).
} 
Figure 3: Structure of active enterprises by sector, business economy, 2012 (\%)

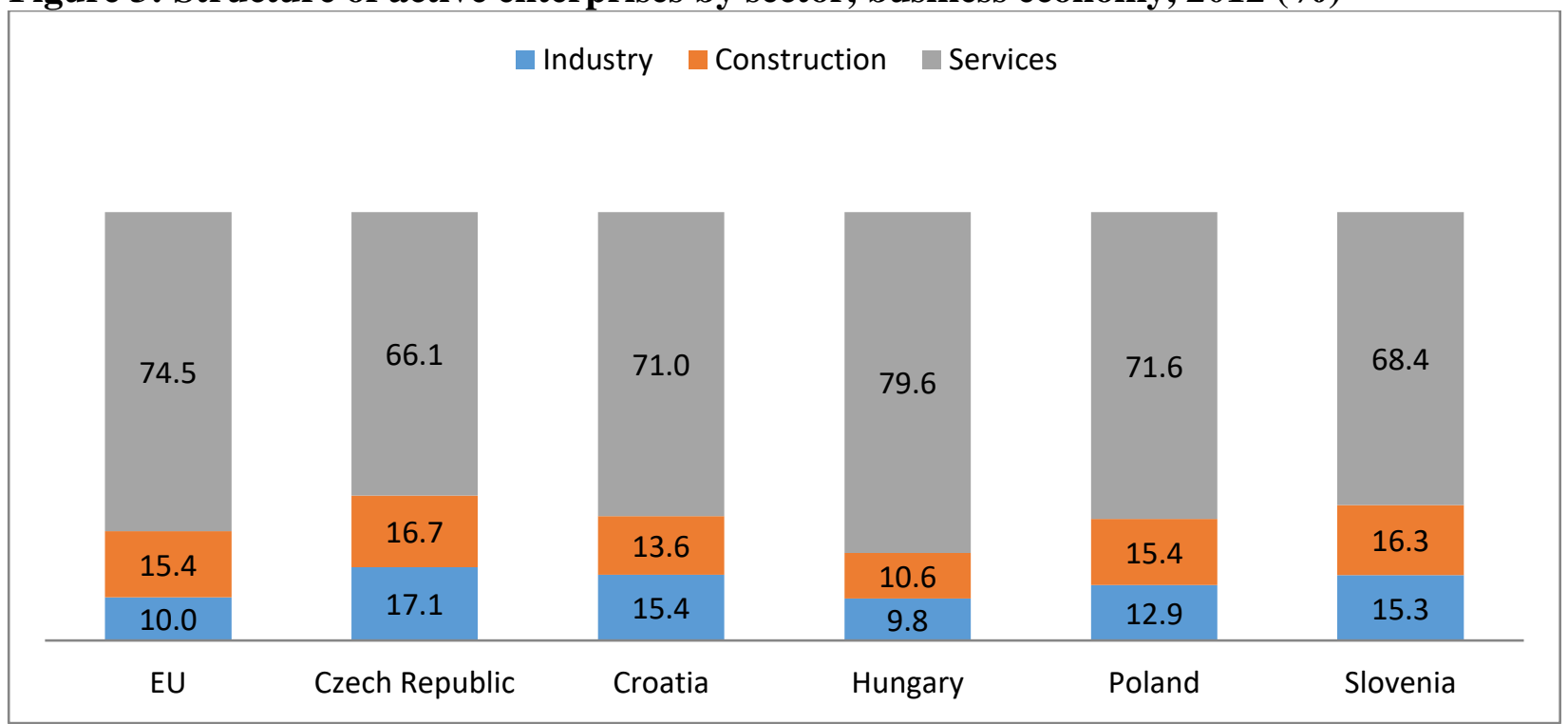

Note: (EU:2010; (2012) - not available;) Source: Eurostat (bd_9b_sz_cl_r2).

Enterprise births are often thought to be a key determinant of job creation and economic growth as newly emerging competition stimulates a country's enterprise population to become more efficient and competitive. At the EU level, enterprise birth and death rates average about $10 \%$ of the total number of enterprises. As can be seen in Figure 4, there were more enterprise deaths than births in 2009, both at the EU level and in the selected CE countries. Compared with aggregate EU values, the Czech Republic, Poland and Slovenia recorded higher enterprise birth rates. A comparison of the data for enterprise births in 2009 with the data for 2012 shows that the proportion of enterprise births in the selected CE countries decreased in 2012, with birth rates ranging from $8 \%$ in Croatia to $12 \%$ in Poland. The drop in the number of enterprise births was particularly steep in the Czech Republic, while the figure for Hungary remained constant. Overall, the studied CE countries' 2012 enterprise birth figures were not far from the $2009 \mathrm{EU}$ average.

The share of start-ups in B2B services is considered to be the true indicator of advanced economic development. It is the highest in Slovenia (42\%), followed by Croatia and Hungary (GEM, 2013: 24). 
Figure 4: Enterprise birth and death rates, business economy, selected CE countries, 2009, $2012(\%)$

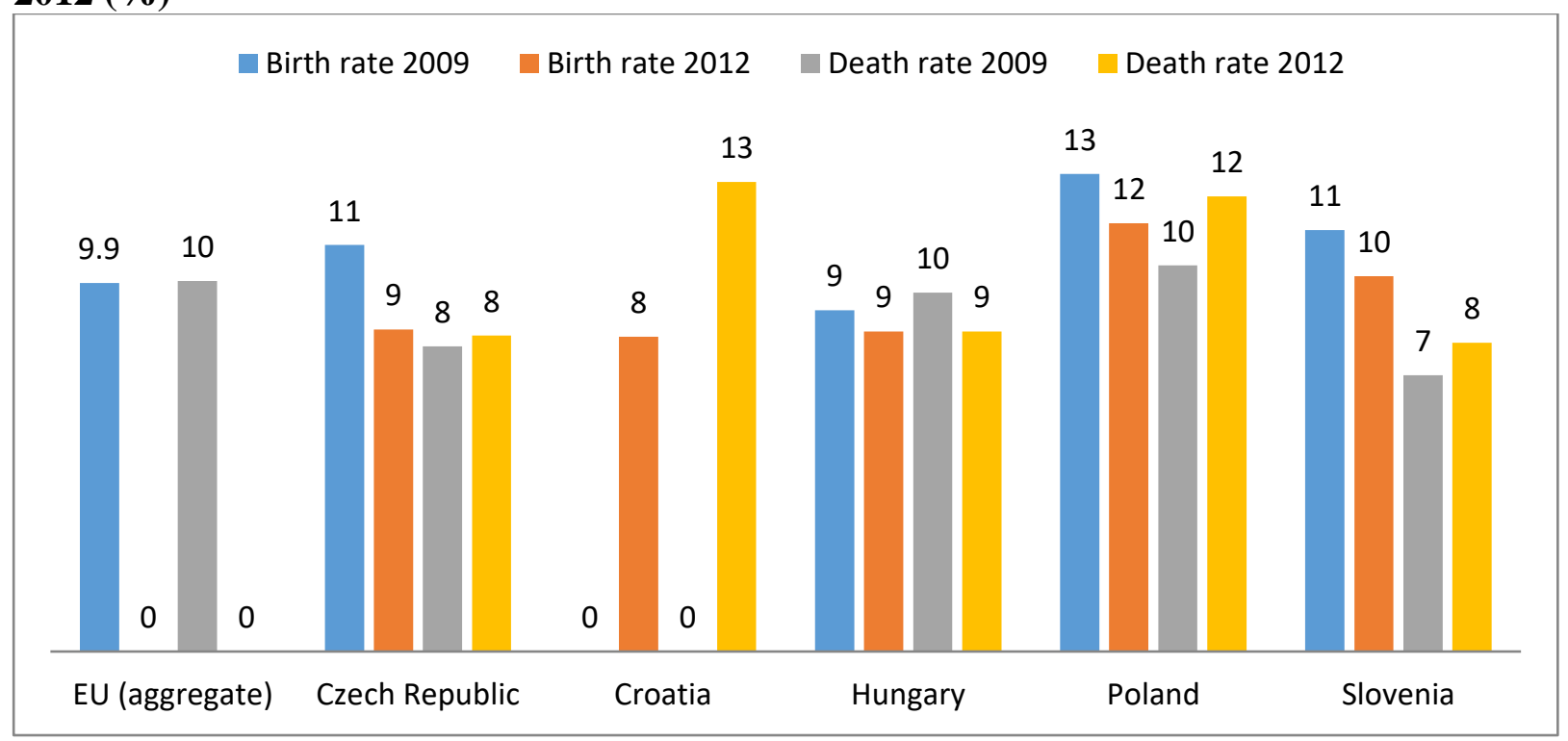

Note: HR (2009) and EU (2012) not available.

Source: Eurostat (bd_9b_sz_cl_r2).

The Czech Republic and Slovenia have the highest share of innovative enterprises (50\%), followed by Croatia, with 40\%, and Poland and Hungary, each with around 30\% (Table 6). In all five countries, large enterprises are the ones that innovate the most. Over $65 \%$ of large enterprises are considered innovators. In Slovenia, the figure is close to $90 \%$. In all five countries, product and/or process and organisation and/or marketing (including enterprises with abandoned/suspended or on-going innovation activities) is the predominant category among innovative enterprises. What is slightly worrying is that, from 2008 to 2010, there was a negative trend in the proportion of innovative enterprises in the Czech Republic, Croatia and Slovenia. Hungary and Poland, meanwhile, had a positive trend. 
Table 6: Enterprises by type of innovation, distribution by size in 2008 and 2010 (share in total number of enterprises)

\begin{tabular}{|c|c|c|c|c|c|c|c|c|c|c|c|}
\hline \multirow[t]{2}{*}{$\begin{array}{l}\text { COUNTR } \\
Y\end{array}$} & \multirow[t]{2}{*}{ SIZE } & \multicolumn{2}{|c|}{$\begin{array}{l}\text { INNOVATIVE } \\
\text { ENTERPRISES } \\
\text { (INCLUDING } \\
\text { ENTERPRISES } \\
\text { WITH } \\
\text { ABANDONED/SUS } \\
\text { PENDED OR ON- } \\
\text { GOING } \\
\text { INNOVATION } \\
\text { ACTIVITIES) }\end{array}$} & \multicolumn{2}{|c|}{$\begin{array}{l}\text { PRODUCT } \\
\text { AND/OR } \\
\text { PROCESS } \\
\text { INNOVATIVE } \\
\text { ENTERPRISES } \\
\text { ONLY } \\
\text { (INCLUDING } \\
\text { ENTERPRISES } \\
\text { WITH } \\
\text { ABANDONED/SUS } \\
\text { PENDED OR ON- } \\
\text { GOING } \\
\text { INNOVATION } \\
\text { ACTIVITIES) } \\
\end{array}$} & \multicolumn{2}{|c|}{$\begin{array}{l}\text { ORGANISATION } \\
\text { AND/OR } \\
\text { MARKETING } \\
\text { INNOVATIVE } \\
\text { ENTERPRISES } \\
\text { ONLY }\end{array}$} & \multicolumn{2}{|c|}{$\begin{array}{l}\text { PRODUCT AND/OR } \\
\text { PROCESS AND } \\
\text { ORGANISATION } \\
\text { AND/OR MARKETING } \\
\text { INNOVATIVE } \\
\text { ENTERPRISES ONLY } \\
\text { (INCLUDING } \\
\text { ENTERPRISES WITH } \\
\text { ABANDONED/SUSPEND } \\
\text { ED OR ON-GOING } \\
\text { INNOVATION } \\
\text { ACTIVITIES) }\end{array}$} & \multicolumn{2}{|c|}{$\begin{array}{l}\text { NON-INNOVATIVE } \\
\text { ENTERPRISES }\end{array}$} \\
\hline & & $\begin{array}{l}\text { CIS } \\
2008\end{array}$ & CIS 2010 & $\begin{array}{l}\text { CIS } \\
2008\end{array}$ & $\begin{array}{l}\text { CIS } \\
2010\end{array}$ & $\begin{array}{l}\text { CIS } \\
2008\end{array}$ & $\begin{array}{l}\text { CIS } \\
2010\end{array}$ & $\begin{array}{l}\text { CIS } \\
2008\end{array}$ & CIS 2010 & $\begin{array}{l}\text { CIS } \\
2008\end{array}$ & CIS 2010 \\
\hline \multirow{4}{*}{$\begin{array}{l}\text { CZECH } \\
\text { REPUBLI } \\
\text { C }\end{array}$} & Total & $56.00 \%$ & $51.69 \%$ & $8.96 \%$ & $9.26 \%$ & $16.72 \%$ & $16.93 \%$ & $30.32 \%$ & $25.50 \%$ & $44.00 \%$ & $48.31 \%$ \\
\hline & $\begin{array}{l}\text { Small } \\
\text { enterprises }\end{array}$ & $52.26 \%$ & $46.65 \%$ & $8.41 \%$ & $8.23 \%$ & $17.72 \%$ & $17.11 \%$ & $26.13 \%$ & $21.32 \%$ & $47.74 \%$ & $53.35 \%$ \\
\hline & $\begin{array}{l}\text { Medium } \\
\text { sized } \\
\text { enterprises }\end{array}$ & $63.53 \%$ & $63.98 \%$ & $10.22 \%$ & $12.37 \%$ & $14.68 \%$ & $17.44 \%$ & $38.62 \%$ & $34.17 \%$ & $36.47 \%$ & $36.02 \%$ \\
\hline & $\begin{array}{l}\text { Large } \\
\text { enterprises }\end{array}$ & $80.72 \%$ & $78.60 \%$ & $11.87 \%$ & $12.60 \%$ & $10.19 \%$ & $12.44 \%$ & $58.66 \%$ & $53.56 \%$ & $19.28 \%$ & $21.40 \%$ \\
\hline \multirow[t]{4}{*}{$\begin{array}{l}\text { CROAT } \\
\text { IA }\end{array}$} & Total & $44.17 \%$ & $42.43 \%$ & $10.27 \%$ & $9.35 \%$ & $9.68 \%$ & $10.56 \%$ & $24.23 \%$ & $22.52 \%$ & $55.83 \%$ & $57.57 \%$ \\
\hline & $\begin{array}{l}\text { Small } \\
\text { enterprises }\end{array}$ & $39.35 \%$ & $38.62 \%$ & $9.80 \%$ & $8.25 \%$ & $9.84 \%$ & $10.69 \%$ & $19.71 \%$ & $19.68 \%$ & $60.65 \%$ & $61.38 \%$ \\
\hline & $\begin{array}{l}\text { Medium } \\
\text { sized } \\
\text { enterprises }\end{array}$ & $57.26 \%$ & $52.89 \%$ & $11.99 \%$ & $13.84 \%$ & $9.76 \%$ & $10.95 \%$ & $35.51 \%$ & $28.20 \%$ & $42.74 \%$ & $47.11 \%$ \\
\hline & $\begin{array}{l}\text { Large } \\
\text { enterprises }\end{array}$ & $78.71 \%$ & $73.12 \%$ & $11.61 \%$ & $12.54 \%$ & $6.45 \%$ & $6.81 \%$ & $60.65 \%$ & $54.12 \%$ & $21.29 \%$ & $26.88 \%$ \\
\hline \multirow[t]{4}{*}{$\begin{array}{l}\text { HUNGA } \\
\text { RY }\end{array}$} & Total & $28.94 \%$ & $31.06 \%$ & $7.08 \%$ & $7.50 \%$ & $8.16 \%$ & $12.65 \%$ & $13.70 \%$ & $10.92 \%$ & $71.06 \%$ & $68.94 \%$ \\
\hline & $\begin{array}{l}\text { Small } \\
\text { enterprises }\end{array}$ & $24.46 \%$ & $25.94 \%$ & $5.55 \%$ & $5.84 \%$ & $8.14 \%$ & $12.66 \%$ & $10.77 \%$ & $7.44 \%$ & $75.54 \%$ & $74.06 \%$ \\
\hline & $\begin{array}{l}\text { Medium } \\
\text { sized } \\
\text { enterprises }\end{array}$ & $39.55 \%$ & $45.92 \%$ & $11.89 \%$ & $13.25 \%$ & $8.28 \%$ & $13.25 \%$ & $19.38 \%$ & $19.43 \%$ & $60.45 \%$ & $54.08 \%$ \\
\hline & $\begin{array}{l}\text { Large } \\
\text { enterprises }\end{array}$ & $67.12 \%$ & $69.60 \%$ & $15.25 \%$ & $15.78 \%$ & $7.92 \%$ & $9.63 \%$ & $43.95 \%$ & $44.19 \%$ & $32.88 \%$ & $30.40 \%$ \\
\hline \multirow[t]{4}{*}{$\begin{array}{l}\text { POLAN } \\
\text { D }\end{array}$} & Total & $27.94 \%$ & $28.14 \%$ & $7.89 \%$ & $6.81 \%$ & $8.14 \%$ & $11.95 \%$ & $11.90 \%$ & $9.38 \%$ & $72.06 \%$ & $71.86 \%$ \\
\hline & $\begin{array}{l}\text { Small } \\
\text { enterprises }\end{array}$ & $22.41 \%$ & $22.53 \%$ & $6.32 \%$ & $4.76 \%$ & $8.08 \%$ & $12.17 \%$ & $8.01 \%$ & $5.60 \%$ & $77.59 \%$ & $77.46 \%$ \\
\hline & $\begin{array}{l}\text { Medium } \\
\text { sized } \\
\text { enterprises }\end{array}$ & $39.97 \%$ & $40.09 \%$ & $12.05 \%$ & $12.39 \%$ & $8.40 \%$ & $11.53 \%$ & $19.52 \%$ & $16.17 \%$ & $60.04 \%$ & $59.91 \%$ \\
\hline & $\begin{array}{l}\text { Large } \\
\text { enterprises }\end{array}$ & $66.71 \%$ & $67.77 \%$ & $15.29 \%$ & $15.21 \%$ & $8.01 \%$ & $10.19 \%$ & $43.46 \%$ & $42.37 \%$ & $33.29 \%$ & $32.23 \%$ \\
\hline \multirow[t]{4}{*}{$\begin{array}{l}\text { SLOVE } \\
\text { NIA }\end{array}$} & Total & $50.28 \%$ & $49.40 \%$ & $9.12 \%$ & $10.22 \%$ & $15.93 \%$ & $14.69 \%$ & $25.23 \%$ & $24.48 \%$ & $49.72 \%$ & $50.63 \%$ \\
\hline & $\begin{array}{l}\text { Small } \\
\text { enterprises }\end{array}$ & $44.51 \%$ & $43.12 \%$ & $8.18 \%$ & $9.16 \%$ & $16.92 \%$ & $15.72 \%$ & $19.41 \%$ & $18.25 \%$ & $55.49 \%$ & $56.88 \%$ \\
\hline & $\begin{array}{l}\text { Medium } \\
\text { sized } \\
\text { enterprises }\end{array}$ & $63.40 \%$ & $65.46 \%$ & $12.12 \%$ & $13.65 \%$ & $14.13 \%$ & $12.92 \%$ & $37.15 \%$ & $38.77 \%$ & $36.60 \%$ & $34.54 \%$ \\
\hline & $\begin{array}{l}\text { Large } \\
\text { enterprises }\end{array}$ & $89.20 \%$ & $86.78 \%$ & $11.74 \%$ & $12.64 \%$ & $7.98 \%$ & $4.60 \%$ & $69.95 \%$ & $68.97 \%$ & $10.80 \%$ & $13.22 \%$ \\
\hline
\end{tabular}

Source: Authors' calculations based on Eurostat, CIS database.

R\&D spending in OECD and EU countries either stagnated or decreased on average as a result of the financial crisis from 2008 to 2012 (Figure 5). 


\section{Figure 5: Gap between R\&D intensities in OECD, EU28 and selected CE countries, as a percentage of GDP, 1992-2012 or latest available year.}

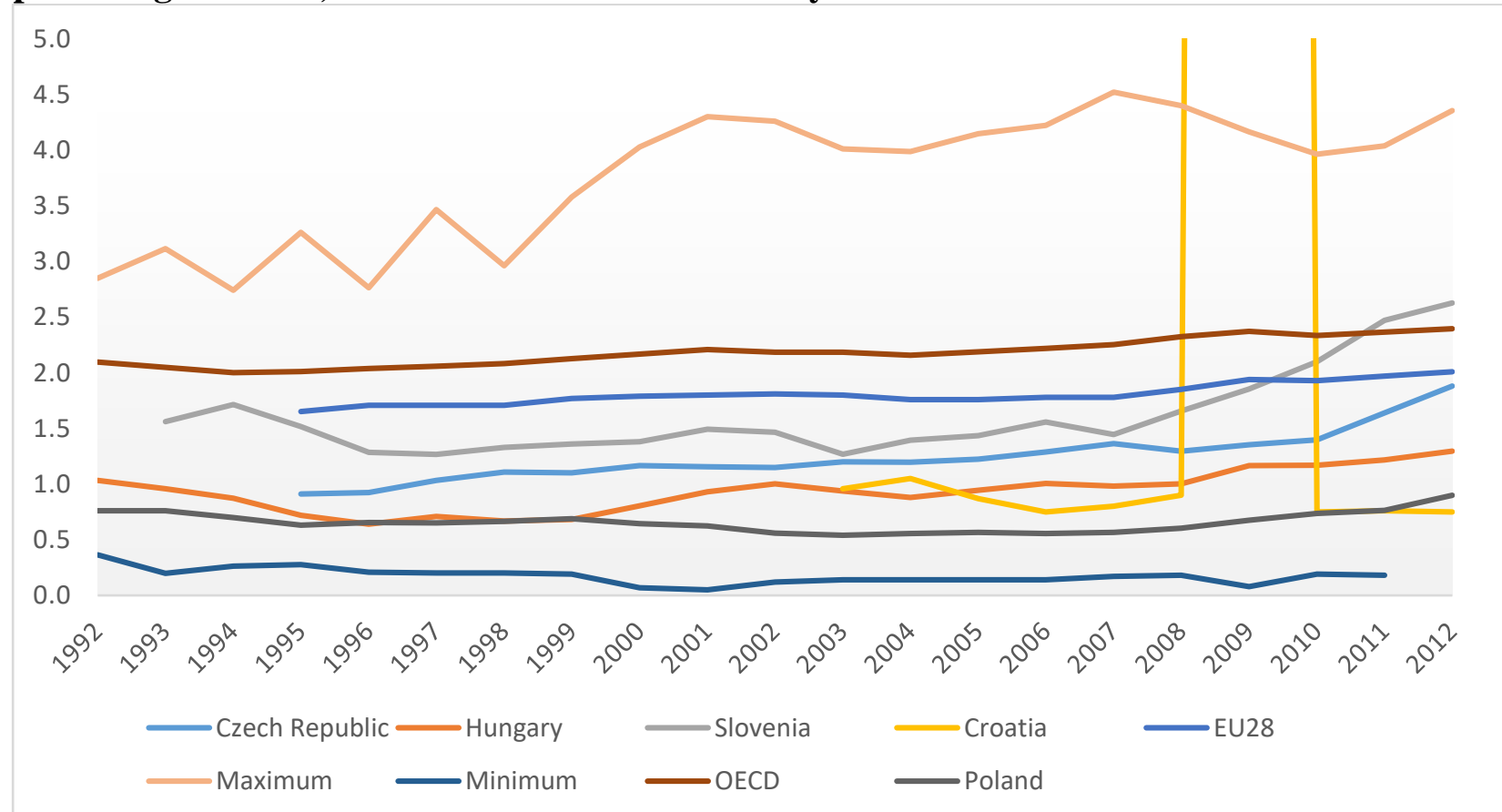

Note: Adapted by authors, based on OECD STI Outlook 2014, Chapter 1, Fig 1.14.

The OECD's share in global R\&D spending declined from $90 \%$ in 1992 to $70 \%$ in 2012. Recent OECD studies (OECD, 2014) find that R\&D spending by most OECD governments and businesses has yet to recover from the economic crisis. In many countries, public R\&D budgets stagnated or shrank while business investment was subdued. As a result, annual growth in $R \& D$ spending across OECD countries was $1.6 \%$ over 2008-2012, while EU28 R\&D spending stagnated from 2009 to 2012. R\&D spending in Central European countries varies as some countries approach the 3\%-of-GDP-for-research target set up by the European Strategy 2020. Slovenia invests $2.59 \%$ of GDP in R\&D. Hungary and the Czech Republic also increased their R\&D spending, while Poland stagnated and Croatia decelerated due to a drop in investment to a modest $0.75 \%$ of GDP.

The expeditious recovery of Poland and Hungary after the fall of the Berlin Wall in 1989 was supported by the EU's PHARE programme, originally created in 1989 to assist the restructuring of the Polish and Hungarian economies and later expanded to include 10 more countries, the Czech Republic and Slovenia among them. Unlike the countries that became EU members during the fifth round of the EU's enlargement in 2004, Croatia became a member state almost a decade later, in 2013. Being a member of the EU enables Croatia to access ESI funds, which represents a remarkable opportunity to address needs in research, innovation and skills. For example, the amount of funds reserved for Croatia is estimated at $€ 1.5$ billion annually in the 2014-2020 period (World Bank, 2014). 
In addition to receiving funding opportunities, the emerging economies have undergone a process of extensive modernisation of their research and innovation systems through the process of Europeanisation. Their research and innovation systems are thus largely determined by the common European research and innovation strategy, which fosters a transition to a knowledge economy to overcome stagnation. Europeanisation refers to a common vision of strategic development of Europe and its member states and is most often associated with the adaptation of domestic arrangements or reforms in different areas to meet European requirements through three Europeanisation mechanisms: institutional compliance, changing domestic opportunity structures, and framing domestic beliefs and expectations (Knill and Lehmkuhl 2002).

The member states were therefore expected to deliver national smart specialisation strategies in 2014. For example, Poland's smart specialisation efforts are rooted in multiple foresight projects commissioned by the Ministry of Science and Higher Education and the Ministry of Economy. Sixteen specific specialisation areas were identified at the national level, while Polish regions have their own S3 documents (Erawatch, 2013). The European Commission has accepted smart specialisation strategies from all the studied countries except Croatia, whose strategy is still being evaluated. The preparation of Croatia's national S3 strategy has resulted in a number of analytical input documents (including business expenditure on R\&D, cross-sector competitive advantage analysis, technology usage and availability, and KET deployment), contributing to a better understanding of the current situation and directions to be followed.

\section{Facilitating institutions (R\&D labs, multinational firm research centres, university-based science and innovation centres)}

Poland increased the number of innovation centres from 195 in 1995 to 735 in mid-2010, using EU funds and technical assistance (PAED, 2011)). Many of the EU-funded facilities are entrepreneurship centres, training and advisory centres, business centres, consulting centres, and entrepreneurship incubators driven by bottom-up activities to strengthen entrepreneurial spirit and support the influx of newcomers to entrepreneurship. Croatia, owing to the efforts of its Ministry of Entrepreneurship and Crafts, has established 88 business support organizations: 21 regional development agencies, 10 local development agencies, 16 business incubators, six technology parks, and 35 business centres (MEC, 2013).

The European Portal on Research Infrastructures Database is a source of data on a large number of Research Infrastructures of pan-European interest in all fields of science. It lists facilities, resources and related services used by scientific communities conducting top-level research in various fields ${ }^{5}$.

The first infrastructure identified by the ESFRI to be located in new member states is the Extreme-Light-Infrastructure (ELI), which will be implemented as a distributed infrastructure in the Czech Republic, Hungary and Romania. The project has an implementation budget of over $€ 845$ million, largely co-financed by structural funds. It is the first time ever that research infrastructures will be used to achieve the objectives of scientific excellence, European cohesion,

\footnotetext{
${ }^{5}$ http://www.riportal.eu/public/index.cfm?fuseaction=ri.search
} 
and regional development. The infrastructure consists of the ELI Beamlines facility located in the Czech Republic, the ELI Nuclear Physics facility in Măgurele (south of Bucharest), Romania, and the ELI Attosecond facility in Szeged, Hungary. According to the Strategy Report on Research Infrastructures (European Union, 2011), the project is a result of a pan-European effort and is thus expected to have a significant scientific and economic impact at both the European and regional levels. It will simultaneously support the development of local research communities and create numerous opportunities for the transfer of knowledge and for collaboration between the research community and industry. The economic impact on the hosting regions and society as a whole might be massive (especially in medicine and materials science) as the benefits created should spread and be shared by all. The project, however, will only be successful if sufficient levels of collaboration are achieved between researchers, innovators, related professionals and local authorities. Finally, there are several goals ELI should achieve at the level of the European Research Area. Firstly, it should significantly contribute to the integration of Europe's research system. Secondly, ELI should facilitate a more balanced distribution of research capacities in the EU and, finally, it should provide opportunities for an increased mobility of researchers and knowledge.

Another project focused on East European users is EAST-NMR (Enhancing Access and Services to East European users towards an efficient and coordinated pan-European pool of NMR capacities to enable global collaborative research and boost technological advancements). EASTNMR is a pan-European project that aims to enhance access to NMR instrumentation based in Eastern Europe, enable global collaborative research and boost technological advancements. The project consortium comprises 21 academic and industrial partners from both Eastern and Western Europe working together to achieve an efficient and coordinated pan-European pool of NMR capacities. As a key technology for research in the modern life sciences (e.g. providing a detailed insight into protein-protein and protein-ligand interactions in new areas of molecular systems biology), NMR has an increasing impact on human health.

Since NMR applications in Eastern Europe are sparse and there are few challenging scientific projects underway, EAST-NMR aims to provide transnational access to NMR instrumentation based in Eastern Europe. Benefiting from the experiences of another on-going European project, EAST-NMR will provide access to solid-state NMR facilities, an emerging technology at the international level. The project will also provide for the education and training of researchers, especially those from Eastern Europe.

The National Institute for Biology from Ljubljana and the Institute for Oceanography and Fisheries from Split participate in the pan-European SeaDataNet II: Pan-European infrastructure for ocean and marine data management. SeaDataNet enables the collaboration of major institutes and marine data centres from countries bordering the North-East Atlantic, and the neighbouring seas: the Mediterranean, the Black Sea, the Baltic, the North Sea, and the Arctic. All emerging CE countries except the Czech Republic participate in the project. The aim is to standardise a system for the management of large and diverse data sets collected by oceanographic fleets and automatic observation systems. It has been established that there are more than 600 laboratories that collect scientific data in both the public and private sectors. Diverse data (physical, geological and biological) are collected using a variety of sensors on board research vessels, submarines, fixed and drifting platforms, airplanes and satellites. Since the collected data are 
neither easily accessible nor standardized, the project aims to enhance their validity, security and availability.

The Triple Helix model of university-industry-government relations (e.g. Etzkowitz and Leydesdorff 2000, Ranga and Etzkowitz 2013) has not had much impact in the studied CE countries as some of their structural characteristics impeded the diffusion and use of the model. For instance, their universities are primarily teaching institutions with relatively low levels of academic research and entrepreneurial activities (patenting, licensing, formation of academic spin-offs and incubation). Next, their domestic firms have weak R\&D capacity and internal R\&D demand. And finally, public and private R\&D spending is low. There is virtually no seed capital while horizontal policy co-ordination is weak. Even though some dramatic improvements have occurred within and among the University, Industry and Government Institutional spheres over the last decade, it is not clear whether these recent transformations enable the application of a Triple Helix-based innovation strategy in these countries.

\section{Conclusion and recommendations}

The analysed countries — Poland, the Czech Republic, Hungary, Slovenia, and Croatia — have made huge progress towards a modern innovation-driven economy in the last 20 years. However, they are still struggling with the implications of the economic downturn caused by the crisis of 2008 and are trying to return to their pre-crisis levels of economic prosperity. Their posttransition development is significantly uneven in terms of economic strength and resilience to the economic crisis. The countries differ in the rate of recovery and their economic indicators seem to diverge from those of most old EU member states. Poland and Hungary are forging ahead, with positive growth rates in 2013. They are followed by Slovenia and the Czech Republic, while Croatia is lagging behind due to eight consecutive years of economic recession. The current state of the economies has been determined by the speed of transition, which was affected by specific national factors and differences, such as the pace of structural reforms (for example, in public administration), the size of internal markets, the ability to absorb EU Structural Funds, and the structure of the economy.

Entrepreneurship in these countries is hindered by too much bureaucracy, over-regulation, and high labour costs, which impede growth, innovation and reforms in private-sector companies and public policies. Reforms receive remarkable backing from EU supporting programmes for SMEs, technology, and research. Programmes such as Horizon 2020 (e.g. collaborative projects, the SME Instrument, Eurostars) and the European Structural and Investment Funds (ESIF) are tailored to foster innovation-based companies and promote socio-economic development and cohesion among the "old" and "new" states to enable the prosperity of both. The efficient use of the ESIF, combined with the bottom-up approach to smart specialisation strategies at the national and regional levels, is a promising mechanism for European integration and a harmonised innovation system at the EU level.

The experience of the past 25 years shows that the EU has helped these countries to actively support SMEs from both the manufacturing and service sectors in areas including research and development and innovation. In all five countries, large enterprises are the ones that innovate the 
most. More than $65 \%$ of large enterprises in these countries are considered to be innovators (in Slovenia the figure is close to $90 \%$ ). In Slovenia, business expenditure on R\&D as a percentage of GDP stands at $2.16 \%$, exceeding the EU average of $1.31 \%$. Other countries, especially Poland and Croatia, do not follow this path. Technological progress and greater innovation dynamics in these countries require more concentrated and coordinated efforts by private businesses and public policy makers, with a special focus on bolstering innovativeness among SMEs.

It is expected that economic growth in Central and Eastern European countries will continue to exceed the eurozone average (EIU, 2015:17). This growth will increasingly be driven by small and medium-sized enterprises, which provide many business opportunities for both foreign and domestic investors. 


\section{References}

1. Archibugi, D., Coco, A. (2005), Is Europe Becoming the Most Dynamic Knowledge Economy in the World?, Journal of Common Market Studies, Vol. 43, No. 3, pp. 433-459, September 2005.

2. Archibugi, D., Filippetti, A. (2011), Is the Economic Crisis Impairing Convergence in Innovation Performance Across Europe?, Journal of Common Market Studies, Vol. 49, No. 6, pp. 1153-1182, DOI: 10.1111/j.1468-5965.2011.02191.x

3. Becic, E.; Dabic, M. (2012), An Analysis of Research and Innovation in Croatia, [in:] Dabic, Marina; Potočan, Vojko (eds.) (2012), Entrepreneurship and Innovation, University of Zagreb, University of Maribor , ISBN 978-961-6802-09-3 (Faculty of Economics and Business Maribor) ISBN 978-953-6025-52-7 (University of Zagreb, Faculty of Economics and Business, Zagreb) pp. 67-99.

4. Bučar, Maja and Stare Metka (2014) Evolution of Innovation Policy in Slovenia since 2004 Promises and Pitfalls; Studia Historica Slovenica; forthcoming.

5. Deloitte (2013), Top 500, Central Europe, Deloitte, http://www.deloitte.com/assets/DcomSerbia/Local\%20Assets/Documents/2013/Top500\%202013\%20final\%20.pdf

6. EIU (2015), The Economist (2015), A report by The Economist Intelligence Unit 2015 available at: http://www.economistinsights.com/countries-tradeinvestment/analysis/business-risks-and-opportunities-central-and-eastern-europe/fullreport (accessed 7 June 2015).

7. Erawatch (2013), Erawatch County Report, Poland, 2013.

8. Erawatch (2013a), Erawatch County Report, Hungary, 2013.

9. European Commission (2002), European Trend Chart on Innovation: European Innovation Scoreboard, Technical Paper No. 3, European Commission, 28 November 2002.

10. European Commission (2005), Working Together for Growth and Jobs: A New Start for the Lisbon Strategy, COM (2005) 24 final, Brussels, 2 February 2005.

11. European Commission (2010), Europe 2020 - A Strategy for Smart, Sustainable and Inclusive Growth, COM (2010) 2020, Brussels, 3 March 2010.

12. European Commission (2011), Innovation Union Competitiveness Report, EUR 24211, Brussels.

13. European Commission (2011a), Horizon 2020 - The Framework Programme for Research and Innovation, Brussels, XXX, COM (2011) 808/3, Brussels.

14. European Commission (2013), Research and Innovation Performance in EU Member States and Associated Countries, Innovation Union Progress at Country Level 2013, European Commission, Brussels.

15. European Commission (2014), Innovation Union Scoreboard 2014, European Commission, Brussels.

16. European Commission (2014a), Annual Report on European SMEs 2013/2014 - A Partial and Fragile Recovery, Final Report, July 2014, European Commission, Brussels.

17. European Council (2000), Presidency Conclusions, 100/1/00, Lisbon, 23-24 March 2000.

18. European Union (2011), Strategy Report on Research Infrastructures, Roadmap 2010, European Strategy Forum on Research Infrastructure, European Union.

19. Freeman, C. (1987), Technology, Policy and Economic Performance: Lessons from Japan. Pinter Publishers, London.

20. GEM (2013), Global Entrepreneurship Monitor Report -Poland 2012, Polish Agency of Enterprise Development (PARP) and University of Economics in Katowice, Warsaw 2013. 
http://www.gemconsortium.org/country-profile/99

21. Knill, C., Lehmkuhl, D. (2002), The National Impact of European Union Regulatory Policy: Three Europeanization Mechanisms, European Journal of Political Research, Vol. 41, No. 2. pp. 255-280.

22. Koekoek, Peter (2012), Innovative Companies: Making Europe the Best Place to Grow Highly Innovative ICT SMEs, Report of a High-Level Panel Discussion DG Connect, (2012) http://ec.europa.eu/digital-agenda/sites/digital agenda/files/2._Innovative_companies_Report_Final.doc.pdf Brussels, accessed 24 October 2015.

23. Kuhlmann, S. (2001), Future Governance of Innovation Policy in Europe-Three Scenarios, Research Policy 30, pp. 953-76.

24. Lumpkin, G.T., and Dess, G.G. (1996), Clarifying the Entrepreneurial Orientation Construct and Linking It to Performance, Academy of Management, Vol. 21, No. 1, pp. 135-172.

25. Lundvall, B.-A. (ed.), (1992), National Systems of Innovation. Towards a Theory of Innovation and Interactive Learning, London: Pinter.

26. MEC (2013), The Croatian SME Observatory Report 2013, Ministry of Entrepreneurship and Crafts, Zagreb.

27. OECD (2014), Science and Industry Outlook 2014, OECD, Paris.

28. PAED (2011), Innovation Centers in Poland, The Polish Agency for Enterprise Development, Warsaw.

29. Radošević, S. (1996), Restructuring of R\&D Institutes in Post-Socialist Economies: Emerging Patterns and Issues, chapter in Webster, Andrew (ed.): Building New Bases for Innovation: The Transformation of the R\&D System in Post-Socialist States, Anglia Polytechnic University, Cambridge, 1996, pp. 8-30.

30. Švarc, J. (2011), Does Croatian National Innovation System (NIS) Follow the Path Towards Knowledge Economy?, International Journal of Technology Transfer and Commercialisation, Vol. 10, No. 2, pp.131-151.

31. Technopolis (2014), Evaluation of Pertinence and Impact of Research Infrastructure Activity in FP7 -EPIRIA, Technopolis group, Brussels.

32. World Bank (2014), Croatia Partnership Country Program Snapshot, World Bank Group, April 2014, web pages. 